
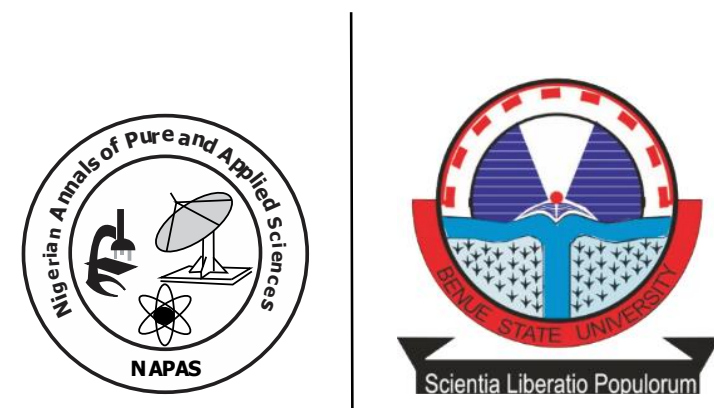

\title{
Species Composition of Mosquitoes from Boarding School Dormitories in Benin City, Edo State, Nigeria
}

${ }^{* 1}$ Omoregie, A. 0., ${ }^{20}$ moregie, M. E., 1,3Adetimehin, A. D. and ${ }^{1}$ Aigbodion, F. I.

1. Department of Animal and Environmental Biology, Faculty of Life Sciences, University of Benin, Benin City, Nigeria.

2. Department of Crop Science, Faculty of Agriculture, University of Benin, Benin City, Nigeria.

3. Molecular Entomology and Vector Control Research Laboratory, Department of Public Health and Epidemiology, Nigerian Institute of Medical Research, Lagos, Nigeria.

*Corresponding Author: anthony.omoregie@uniben.edu

\begin{abstract}
This study investigated the distribution, species composition, and sex ratio of indoor resting mosquitoes alongside their relationship with climatic conditions in school dormitories located in Egor, Oredo and Ikpoba-okha Local Government Areas (LGAs) respectively in Benin City, Edo State, Nigeria. Indoor resting mosquitoes were collected with the aid of a sweep net and mechanical aspirator from randomly selected school dormitories between $08.00 \mathrm{hr}$ and $11.00 \mathrm{hr}$ from November (2011) to June (2012). The mosquitoes collected were identified using published morphological identification keys. A total of 766 mosquitoes containing four species: Culex quinquefasciatus $(\mathrm{n}=724 ; 94.5 \%)$, Anopheles gambiaes.1. $(\mathrm{n}=37 ; 4.8 \%)$, Culexannulioris $(\mathrm{n}=4 ; 0.5 \%)$ and Anopheles funestus $(\mathrm{n}=1 ; 0.1 \%)$ in descending order of importance, were collected. Cx.quinquefasciatus was the most predominant mosquito species in school dormitories across the three LGAs. Cx. annulioris and An. gambiaes.1 were most abundant in school dormitories located in Oredo and Ikpoba-okha LGAs respectively. An.funestus occurred only in school dormitories located in Oredo LGA. Analysis of the relationship between meteorological data and species abundance varied significantly $(P<0.05)$ only among An. gambiaes.l with rainfall. There was significant difference $(P<0.05)$ in the sex ratio for all species obtained from the various locations except $A n$. gambiae and $C x$. annulioris in dormitories located in Oredo LGA Results of this study revealed the high presence of mosquito-borne disease risk within the school dormitories and environ, and therefore, the urgent need for properly planned, executed and regular evaluation of control measures.
\end{abstract}

Keywords: Resting mosquitoes, Culex quinquefasciatus, Anopheles gambiaes.1., Culexannulioris, Anopheles funestus. 


\section{Introduction}

Mosquitoes are ubiquitous insect pests that have been incriminated overtime to be the predominant vectors of deadly communicable parasitic and arboviral diseases such as malaria, filariasis, dengue fever, yellow fever, chikunguya and zika virus affecting humans and other animals (Aigbodion et al., 2011; Okorie et al., 2015; Service, 2008). These insect species have also been documented to possess the capacity of transmitting these deadly diseases to about two-fifth of the world population (Nour et al., 2012).

A plethora of publications exist on the abundance, distribution and species composition of mosquitoes across several states in Nigeria (Ajayi et al., 2010; Ajayi et al. 2011; Oduolaet al., 2012; Aigbodion and Uyi, 2013; Adeogun et al., 2017; Aju-Ameh et al., 2017). For instance, a recent study by Awolola et al. (2018) which focused on the pyrethroid resistance intensity of Anopheles species collected from several vector surveillance sites (Lagos, Edo, Ogun, Anambra, Kwara and Niger) in Nigeria, revealed that members of the genus Anopheles namely; Anopheles gambiae, Anopheles coluzzii and Anopheles arabiensis were the three major vectors of malaria in Nigeria. In addition, previous studies by Oyewole et al. (2010), Oringanje et al. (2011), and Oduola et al. (2012) also reported that Anopheles melas and Anopheles funestus play a major role in the transmission of malaria in some states in Nigeria.

Culex pipiens, Culex quinquefasciatus, An. gambiae, An. funestus and An. arabiensis have been found culpable in the transmission of filariasis. Aedes aegyti and Aedes albopiticus play a major role in the transmission of yellow fever and other arboviral diseases in some states in Nigeria (Okorie et al., 2015).

Globally, human populations of over a billion people are at risk of getting infected with lymphatic filariasis, and a vast majority of persons have been reported to suffer from its clinical manifestations (Okorie et al., 2015). In Africa, the prevalence of lymphatic filariasis is on the increase (Aigbodion et al., 2011), and Nigeria has been specifically reported to bear the highest burden with about 80 to 120 million people at risk (Okorie et al., 2013). As of 2017, there were 219 million cases of malaria worldwide with approximately 435,000 deaths arising from the disease (WHO, 2018). Among the fifteen countries in sub-Saharan Africa enlisted by the World Health Organization, Nigeria bears the highest malaria burden and further accounts for $25 \%$ of all malaria cases worldwide (WHO, 2018) contributed to by the increasing malaria incidence also reported in parts of the country (Ebomwonyi et al., 2015). Equally important, children below five years of age were found to be the most vulnerable group affected by the disease (=malaria), accounting for about $66 \%$ of all malaria deaths globally (WHO, 2018). In Part of Edo State, there exist also, evidence of increasing malaria incidence

While studies on the abundance and species composition of mosquitoes in southSouthern Nigeria have been limited to several residential areas within selected local governments of some states such as Rivers, Cross River, Bayelsa, and Akwa Ibom (Oringanje et al., 2011; Ebenezer et al., 2012; Okiwelu and Noutcha, 2012; Itina et al., 2014; Chinwe et al., 2018), studies on the abundance and composition of mosquito species in Edo State are relatively few (Okogun et al., 2005; Aigbodion and Uyi, 2013). Furthermore, reports on the mosquito species composition within residential areas of academic institutions such as school dormitories and hostels amongst others in Edo State are scanty and possibly non-existent. Therefore, this study investigated the abundance and species composition of mosquitoes that rest within the dormitories of school children in randomly selected day/boarding secondary schools within three different local government areas (Egor, Oredo and Ikpoba-okha) in Benin City, Edo State. A further objective of this study was to determine the sex ratio of the mosquito species present alongside the correlation between the mosquito species abundance and the prevailing climatic conditions of the area.

\section{Materials and Methods Study area:}

This study was carried out in randomly selected dormitories of schools located in Egor, Oredo and Ikpoba-okha Local Government Areas (LGAs) respectively in Benin City, south Southern part of Edo State. In Egor Local government area, the selected school dormitories are in a mixed faith-based day/boarding school 
(06 $20.899^{\prime} \mathrm{N}$ and $\left.005^{\circ} 36.677^{\prime} \mathrm{E}\right)$. The school dormitory is divided into two separate sections for males and females respectively. In close proximity with the two sections of the dormitory are water reservoirs with taps where students collect water for washing; a drainage almost always containing used stagnant water and empty tins of pastries amongst other dirt. In Oredo LGA, the selected dormitories are located in a Mission owned boys' day/boarding school $\left(06^{\circ} 19.937^{\prime} \mathrm{N}, 005^{\circ} 38.808^{\prime} \mathrm{E}\right)$. Within the school compound and around the dormitories, are unused/abandoned old open water reservoir tanks with good water retention capacity; a small garden; water run offs from bathrooms and a trench/moat few meters from the school. In Ikpoba-okha LGA, the selected dormitories are located in a private owned day/boarding school $\left(06^{\circ} 18.018^{\prime} \mathrm{N}, \quad 005^{\circ} 36.358 \mathrm{E}\right)$. Close to the dormitories is an average size man-made fish pond and a small agricultural garden.

\section{Ethical consideration:}

Before the commencement of the study, consent was obtained from the various school heads at the three sampling locations to access the dormitories.

\section{Sampling of Adult Mosquito:}

Adult mosquitoes were collected in five randomly selected dormitories in each of the Local Government Areas once every fortnightly using a combination of aerial net and mouth aspirator from November 2011 - June 2012. Resting mosquitoes were collected after students-inhabitants of the dormitories had all left for their classroom, from $0800 \mathrm{hr}-1100 \mathrm{hr}$; and an average interval of 30mins was spent in each dormitory. Prior to sampling, hidden places such as underneath sleeping beds, within clothes in wardrobe, around shoes, within cupboards were shook and dusted to dislodge any resting mosquito around there. Flying mosquitoes including those now dislodged were collected suing the aerial net and then aspirated from within the net into the specimen bottles. However, the conventional Pyrethrum spray catch (PSC) method as described by WHO (1975) may have been inappropriate; and this net and aspirator combined use for mosquito collections best suiting, considering the irregularly large sizes of the dormitories that were visited and also the longer time it would take to clear out and re arrange the dormitories pre spray and post spray. Collected mosquitoes were thereafter introduced into appropriately labelled specimen bottles laden with cotton wool and then taken to the Postgraduate Laboratory of the Department of Animal and Environmental Biology, University of Benin, Benin City, Nigeria for further study.

\section{Taxonomic Identification of Mosquitoes:}

In the laboratory, few drops of ethyl acetate were introduced into each specimen bottle and left for about 10 minutes until live wild caught mosquitoes were totally immobilized. Mosquitoes were placed individually on a glass slide and examined at X10 under a Stereomicroscope and identified to the genus and species levels using gross external morphological keys such as the structure and pattern of the antennae, palps, proboscis, terminal abdominal segments, body colour and striations as described by Gillett and Smith (1972).

\section{Collection of Meteorological Data:}

Meteorological data of monthly total rainfall mean monthly temperature and mean monthly Relative Humidity covering November to June was collected from the Nigeria Meteorological Agency (NIMET) Benin Office at the Benin Airport, Benin City.

\section{Statistical Analysis:}

Data collected from the different aspects of this study were analysed using a number of statistical tools including Statistical Package for Social Scientists (SPSS 16.0) and Microsoft Excel, 2010. Data presented in figures and tables were expressed as counts and proportions. OneSample Kolmogorov-Smirnov Test was used to establish variation among mosquito abundance in the various sites and across the months of study. Chi-square Goodness of fit was used to test for significant difference in sex ratio of mosquito vectors collected. Relationship between the occurrence of the mosquito species and weather parameters were determine using the Pearson Correlation Coefficient statistical tool. Other statistical test including the unpaired t-test was used where necessary. Significance in comparisons was set at $P<0.05$ (Ogbeibu, 2005). 


\section{Results}

Mosquito Abundance/Monthly Relative Abundance: A total of 766 mosquitoes belonging to two genera of the family Culicidae - Anopheles and Culex which include Anopheles gambiae, An. funestus, Culex quinquefasciatus and $C x$. Annulioris were collected. Out of the four (4) species of mosquito collected, $C x$. quinquefasciatus was the most abundant (94.5\%), followed by An. gambiae (4.8\%), Cx. annulioris $(0.5 \%)$ and then An. funestus which occurred the least with a percentage occurrence of 0.1 (Table 1). The abundance of the mosquito species per LGA were not statistically significant $(P>0.05)$. However, Culex quinquefasciatus was observed to have a uniform high abundance in school dormitories in Egor LGA $(n=295$; $40.7 \%)$ and Oredo LGA $(\mathrm{n}=245 ; 34.4 \%)$ and the least in Ikpoba-Okha LGA $(\mathrm{n}=180 ; 24.9 \%)$. School dormitories in Ikpoba-Okha LGA had the highest abundance of An. gambiae ( $\mathrm{n}=26$; $70.3 \%)$ and those in Egor LGA, the least $(n=1$; $2.7 \%$ ). Abundance of $C x$. annulioris was highest in school dormitories in Oredo LGA ( $\mathrm{n}=375 \%)$ and none recorded in Ikpoba-Okha LGA. An. funestus occurred only in school dormitories in Oredo LGA with an abundance of $100 \%(n=1)$ (Table 1).

Results of the statistical test done to determine the variations in the mean occurrence of each mosquito species collected across the study months proved significantly different only in An. gambiaes.1. and Cx. Annulioris in Egor dormitories and An. funestusin Oredo $(P<0.05)$. Nevertheless, CX.quinquefasciatus was observed to have the highest relative abundance in all the months in the school dormitories in Egor and Oredo LGAs. Both An. gambiae $(\overline{\mathrm{X}}=0.5 ; 2.4 \%)$ and $C x$. annulioris $(\overline{\mathrm{x}}=0.5 ; 2.1 \%)$ only occurred in the months of November and February respectively in school dormitories in Egor LGA (Figure 1, Table 2). In Oredo LGA school dormitories, An. gambiae only occurred in November $(\overline{\mathrm{x}}=1.5 ; 6.4 \%)$, March $(\overline{\mathrm{x}}=01$; $5.7 \%)$, May $(\overline{\mathrm{x}}=01 ; 7.7 \%)$ and June $(\overline{\mathrm{x}}=1.5$; $12.5 \%)$.Culexannulioris had its highest and lowest monthly abundance in same LGA in January $(\overline{\mathrm{x}}=1 ; 13.3 \%)$ and February $(\overline{\mathrm{x}}=$ $0.33 ; 1.6 \%$ ) respectively. Anopheles funestus only occurred in March $(\overline{\mathrm{x}}=0.5 ; 2.9 \%)$ (Figure 2, Table 3). In school dormitories in Ikpoba-Okha LGA, Cx. quinquefasciatus recorded its highest monthly relative abundance in every other months apart from January, in which no mosquito sample was collected and the month of June wherein it had similar abundance with $A n$. gambiaes.1. $(\overline{\mathrm{x}}=10 ; 55.6$ and $\overline{\mathrm{x}}=8 ; 44.4 \%$ respectively). An. gambiaealso had its highest monthly abundance in June (Figure 3, Table 4).

Sex Ratio: The sex ratio showed a high significant difference $(P<0.05)$ for all species obtained from the various locations except $A n$. gambiae and $C x$. annulioris in dormitories located in Oredo LGA whose sex ratio were not statistically significant $(P>0.05)$ (Table 5).

\section{Association between Climatic Conditions and Mosquito Species Abundance: Test of relationship between climatic conditions including mean monthly temperature $(\%)$, mean relative humidity $(\%)$ and total rainfall $(\mathrm{mm})$ (Table 6) and monthly abundance of individual mosquito species proved a significant correlation only for An. gambiae and rainfall (Table 7).}

Table1: Species abundance of mosquito species sampled per site

\begin{tabular}{lcccc}
\hline \multirow{2}{*}{ SITES } & \multicolumn{4}{c}{$\%($ No) SPECIES } \\
\cline { 2 - 5 } & Culexquinquefasciatus & $\begin{array}{c}\text { Anopheles } \\
\text { gambiae }\end{array}$ & Culexannulioris & $\begin{array}{c}\text { Anopheles } \\
\text { funestus }\end{array}$ \\
\hline Egor LGA & $40.7(295)$ & $2.7(1)$ & $25.0(1)$ & $0.0(0)$ \\
Oredo LGA & $34.4(249)$ & $27.0(10)$ & $75.0(3)$ & $100(1)$ \\
Ikpoba-Okha & $24.9(180)$ & $70.3(26)$ & $0.0(0)$ & $0.0(0)$ \\
LGA & $94.5(724)$ & $4.8(37)$ & $0.5(4)$ & $0.1(1)$ \\
TOTAL & & & & \\
\hline
\end{tabular}




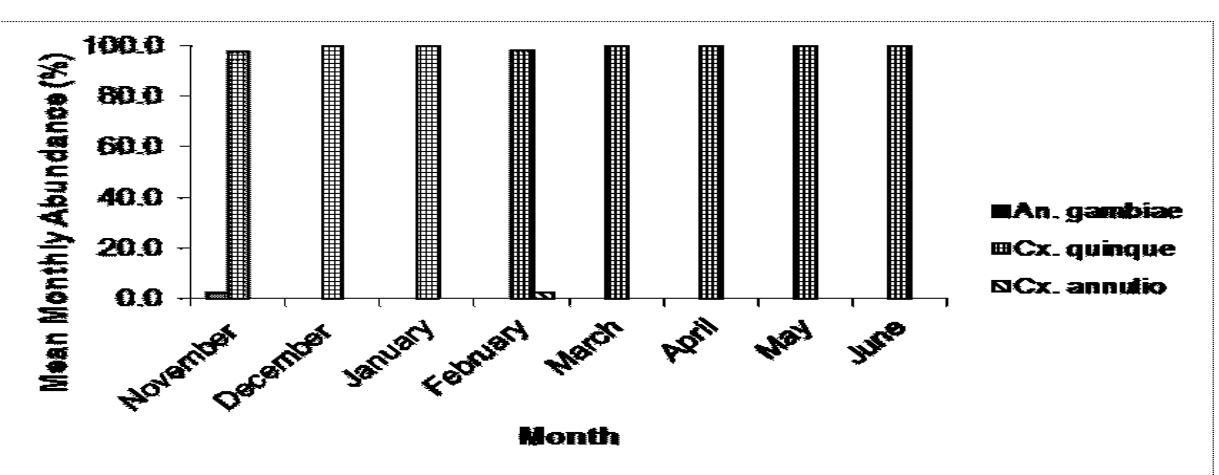

Figure 1: Mean monthly relative abundance of indoor mosquitoes in dormitories in Egor LGA.

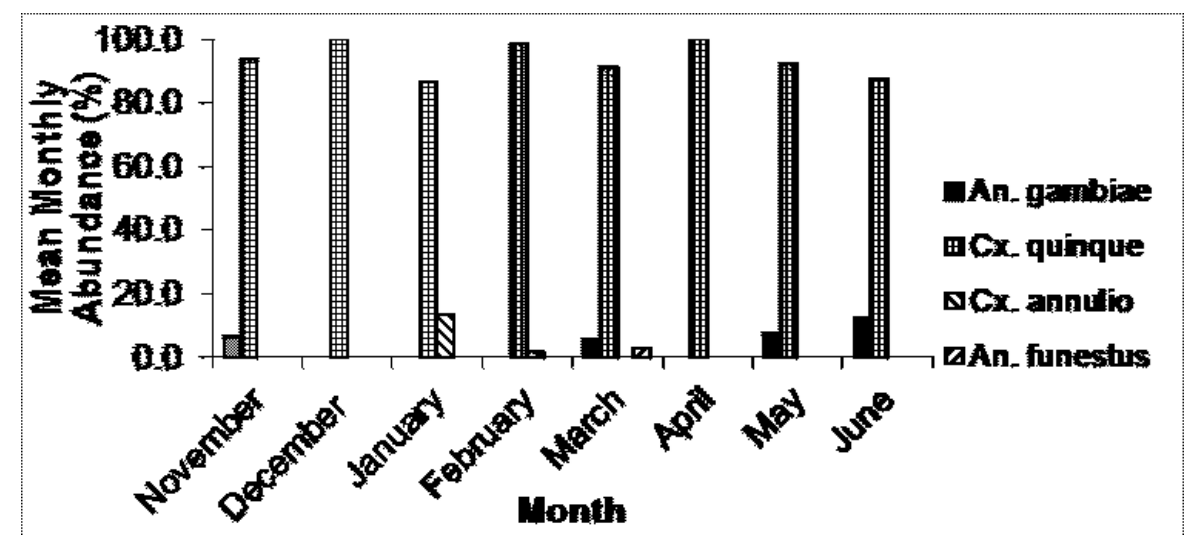

Figure 2:Mean monthly relative abundance of indoor mosquitoes in dormitories in Oredo LGA.

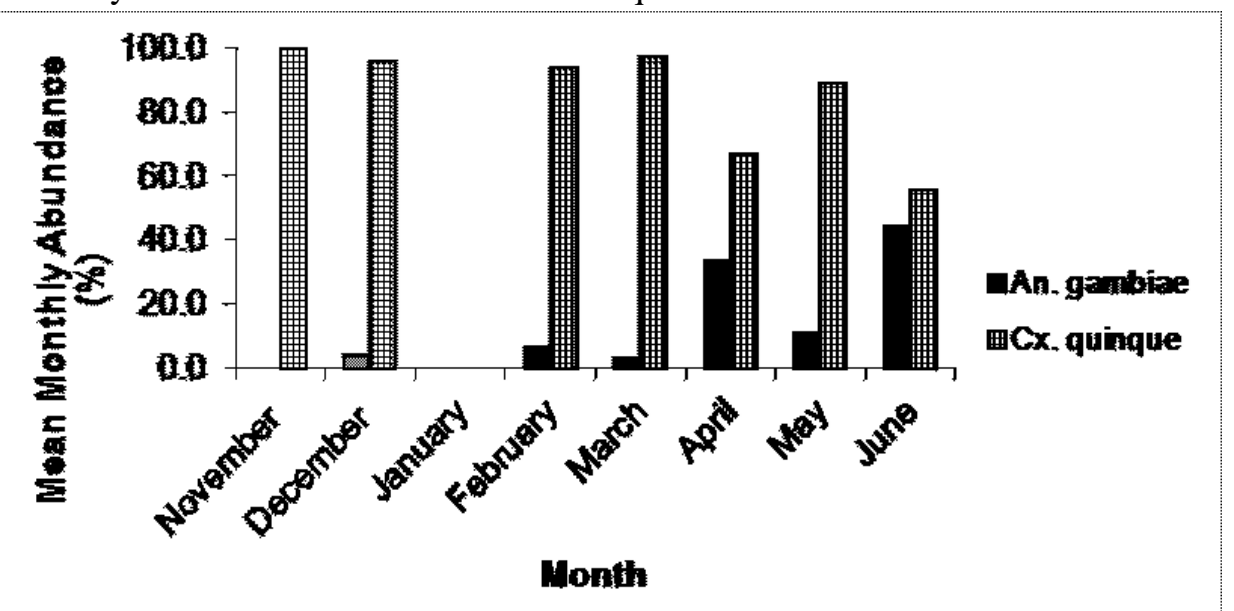

Figure 3: Mean monthly relative abundance of indoor mosquitoes in dormitories in Ikpoba-Okha LGA

Table 2: Monthly abundance of mosquitoes in dormitories in Egor LGA

\begin{tabular}{lcccc}
\hline Month & \multicolumn{2}{c}{ Mosquito Monthly Abundance (\% Relative/Mean) } & Total \\
\cline { 2 - 4 } & An. gambiae & $\begin{array}{c}\text { Cx. } \\
\text { quinquefasciatus }\end{array}$ & \multicolumn{1}{c}{ Cx. annulioris } & \\
\hline November & $2.4(0.5)$ & $97.6(20.5)$ & $0.0(0.0)$ & $100.0(21.0)$ \\
December & $0.0(0.0)$ & $100.0(15.5)$ & $0.0(0.0)$ & $100.0(15.5)$ \\
January & $0.0(0.0)$ & $100.0(10.0)$ & $0.0(0.0)$ & $100.0(10.0)$ \\
February & $0.0(0.0)$ & $97.9(23.5)$ & $2.1(0.5)$ & $100.0(24.0)$ \\
March & $0.0(0.0)$ & $100.0(19.0)$ & $0.0(0.0)$ & $100.0(19.0)$ \\
April & $0.0(0.0)$ & $100.0(15.0)$ & $0.0(0.0)$ & $100.0(15.0)$ \\
May & $0.0(0.0)$ & $100.0(15.5)$ & $0.0(0.0)$ & $100.0(15.0)$ \\
June & $0.0(0.0)$ & $100.0(23.5)$ & $0.0(0.0)$ & $100.0(23.5)$ \\
\hline
\end{tabular}


30| Species Composition of Mosquitoes from Boarding School Dormitories in Benin City, ...

Table 3: Monthly abundance of mosquitoes in dormitories in Oredo LGA

\begin{tabular}{|c|c|c|c|c|c|}
\hline \multirow[t]{2}{*}{ Month } & \multicolumn{4}{|c|}{ Mosquito Monthly Abundance (\% Relative/Mean) } & \multirow[t]{2}{*}{ Total } \\
\hline & $\begin{array}{c}\text { An. } \\
\text { gambiae }\end{array}$ & $\begin{array}{c}C x . \\
\text { quinquefasciatus }\end{array}$ & $\begin{array}{c}C x . \\
\text { annulioris }\end{array}$ & An. funestus & \\
\hline November & $6.4(1.5)$ & $93.6(22.0)$ & $0.0(0.0)$ & $0.0(0.0)$ & $100.0(23.5)$ \\
\hline December & $0.0(0.0)$ & $100.0(18.5)$ & $0.0(0.0)$ & $0.0(0.0)$ & $100.0(18.5)$ \\
\hline January & $0.0(0.0)$ & $86.7(6.5)$ & $13.3(1.0)$ & $0.0(0.0)$ & $100.0(7.5)$ \\
\hline February & $0.0(0.0)$ & $98.4(20.7)$ & $1.6(0.3)$ & $0.0(0.0)$ & $100.0(21.0)$ \\
\hline March & $5.7(1.0)$ & $91.4(16.0)$ & $0.0(0.0)$ & $2.9(0.5)$ & $100.0(17.5)$ \\
\hline April & $0.0(0.0)$ & $100.0(8.0)$ & $0.0(0.0)$ & $0.0(0.0)$ & $100.0(8.0)$ \\
\hline May & $7.7(1.0)$ & $92.3(12.0)$ & $0.0(0.0)$ & $0.0(0.0)$ & $100.0(13.0)$ \\
\hline June & $12.5(1.5)$ & $87.5(10.5)$ & $0.0(0.0)$ & $0.0(0.0)$ & $100.0(12.0)$ \\
\hline
\end{tabular}

Table 4: Monthly abundance of mosquitoes in dormitories in Ikpoba-Okha LGA.

\begin{tabular}{lccc}
\hline Month & Mosquito Monthly Abundance (\% Relative/Mean) & \multirow{2}{*}{ Total } \\
\cline { 2 - 3 } & An. gambiae & Cx. quinquefasciatus & \\
\hline November & $0.0(0.0)$ & $100.0(27.0)$ & $100.0(27.0)$ \\
December & $4.3(0.3)$ & $95.7(7.3)$ & $100.0(7.7)$ \\
January & $0.0(0.0)$ & $0.0(0.0)$ & $0.0(0.0)$ \\
February & $6.5(1.0)$ & $93.5(14.3)$ & $100.0(15.3)$ \\
March & $2.9(0.5)$ & $97.1(17.0)$ & $100.0(17.5)$ \\
April & $33.3(1.0)$ & $66.7(2.0)$ & $100.0(3.0)$ \\
May & $11.1(1.3)$ & $88.9(10.7)$ & $100.0(12.0)$ \\
June & $44.4(8.0)$ & $55.6(10.0)$ & $100.0(18.0)$ \\
\hline
\end{tabular}

Table 5: Sex Ratio of Mosquitoes collected in school dormitories in Benin City.

\begin{tabular}{llccccc}
\hline Site & Species & Male & Female & $\begin{array}{c}\text { Sex } \\
\text { ratio }\end{array}$ & $\begin{array}{c}\text { Chi-Square } \\
\text { value }\end{array}$ & P-value \\
\hline Egor LGA & An. gambiae & 1 & 0 & $1: 0$ & - & - \\
& Cx. quinquefasciatus & 15 & 280 & $1: 19$ & 238.05 & $<0.01$ \\
& Cx. annulioris & 0 & 1 & $0: 1$ & - & - \\
An. funestus & - & - & - & - & - \\
LGedo & An. gambiae & 2 & 8 & $1: 4$ & 3.60 & $>0.05$ \\
& Cx. quinquefasciatus & 48 & 201 & $1: 4$ & 94.01 & $<0.01$ \\
& Cx. annulioris & 1 & 2 & $1: 2$ & 0.33 & $>0.05$ \\
Ikpoba- & An. funestus & 0 & 1 & $0: 1$ & - & - \\
Okha Lambiae & & 4 & 22 & $1: 6$ & 12.46 & $<0.01$ \\
& Cx. quinquefasciatus & 42 & 138 & $1: 3$ & 51.20 & $<0.01$ \\
& Cx. annulioris & - & - & - & - & - \\
& An. funestus & - & - & - & - & - \\
\hline
\end{tabular}


Table 6: Meteorological data for the period of study in Benin City

\begin{tabular}{lccc}
\hline Month & Mean Temperature $\left({ }^{\circ} \mathbf{C}\right)$ & Mean Relative Humidity (\%) & $\begin{array}{c}\text { Total Rainfall } \\
(\mathbf{m m})\end{array}$ \\
\hline November & 28.4 & 82 & 50.2 \\
December & 27.9 & 71 & 0.1 \\
January & 26.9 & 72 & 47.7 \\
February & 27.4 & 86 & 54.1 \\
March & 28.9 & 81 & 74.8 \\
April & 28.3 & 81 & 168.3 \\
May & 27.6 & 85 & 383.6 \\
June & 26.0 & 89 & 532.6 \\
\hline
\end{tabular}

Table 7: Correlation between mosquito species abundance and climatic condition

\begin{tabular}{lcc}
\hline \multicolumn{1}{c}{ Mosquitoes species vs Climatic condition } & Correlation value & P-Value \\
\hline An. gambiaevs Mean Temperature & 0.6 & $\mathrm{p}>0.05$ \\
Cx. quinquefasciatusvs Mean Temperature & 0.3 & $\mathrm{p}>0.05$ \\
Cx. annuliorisvs Mean Temperature & 0.4 & $\mathrm{p}>0.05$ \\
An. funestusvs Mean Temperature & 0.5 & $\mathrm{p}>0.05$ \\
An. gambiaevs Relative Humidity & 0.7 & $\mathrm{p}>0.05$ \\
Cx. quinquefasciatusvs Relative Humidity & 0.5 & $\mathrm{p}>0.05$ \\
Cx. annuliorisvs Relative Humidity & -0.2 & $\mathrm{p}>0.05$ \\
An. funestusvs Relative Humidity & 0.0 & $\mathrm{p}>0.05$ \\
An. gambiaevs Total Rainfall & 0.9 & $\mathrm{p}<0.05$ \\
Cx. quinquefasciatusvs Total Rainfall & -0.1 & $\mathrm{p}>0.05$ \\
Cx. annuliorisvs Total Rainfall & -0.4 & $\mathrm{p}>0.05$ \\
An. funestusvs Total Rainfall & -0.2 & $\mathrm{p}>0.05$ \\
\hline
\end{tabular}

** Correlation is significant at the 0.01 level (2-tailed)

\section{Discussion}

Admittedly, all the species of mosquitoes reported in this study have been previously documented by several authors in Nigeria (Adebote et al., 2008; Okiwelu \& Noutcha, 2012; Umeanaeto et al., 2017) and other countries (Muturi et al., 2008; Mutebi et al., 2012). The dominant species of mosquito encountered in this study was $C x$. quinquefasciatus with an overall abundance of $94.50 \%$ followed by An. gambiae (4.80\%). This finding does not only corroborate with that of Gbaye et al. (2017) who reported that $C x$. quinquefasciatus was the most predominant mosquito species recorded in Idanre and Ese Odo areas in Ondo State, Southwestern, Nigeria, but also supports the findings of Umeanaeto et $a l$., (2017) who studied the parity rate of indoorresting adult mosquitoes within the female hostels of Nnamdi Azikwe University, Akwa, Southeastern Nigeria.
The high abundance and presence of $C x$. quinquefasciatus in the school dormitories located in Egor and Oredo LGAs adjudged to have very close proximity to urban area supports previous accounts by Service (2008), Bockarie et al (2009) and Mullen \& Durden (2009) who reported that $C x$. quinquefasciatus was the dominant mosquito species in most of the urban cities and towns. In spite of this, $C x$. quinquefasciatus also occurred in high numbers in school domitories located in Ikpoba-okha LGA and situated around semi-urban areas. This corroborates with the findings of Okiwelu and Noutcha (2012) who concluded that $C x$. quinquefasciatus have started invading rural areas in lowland rainforest region in Rivers State, Nigeria.

An. gambiae s.l. was the second highest overall abundant mosquito in this study and occurred most in dormitories of schools located in Ikpoba-okha Local Government Area. This finding is in accordance with that of Mzilahowa 
et al. (2016) and Aju-Ameh et al. (2016) who reported that those living in rural areas in Blantyre, Malawi and Gboko, Nigeria respectively, were more exposed to Anopheles mosquito bites and malaria infection than urban inhabitants.

The results of the test of relationship between climatic conditions [mean monthly temperature $(\%)$, mean relative humidity $(\%)$ and total rainfall $(\mathrm{mm})]$ and abundance of individual mosquito species proved a significant correlation only for An. gambiae and rainfall. Anopheles gambiae occurred more in the wet months in this study having its highest mean abundance in June in dormitories in Ikpoba-Okha LGA $(\bar{X}=8$;

44.4\%) when rainfall had its peak. This agrees with reports by Bruce-Chwatt (1952) that breeding activities of the An. gambiae s.l. increased with inrease in rainfall.

The presence of improperly channelled drains, fish pond, and/or moats in and around the vicinities of the school dormitories may have affected the mosquito species composition and abundance across all the study locations. The school dormitories in Oredo LGA were relatively closer to the moat around it than the other study locations. Moats as it were, originally serve as natural drainages that connect to rivers or larger water bodies. However, the incessant dumping of refuse and household wastes in and around them over the years, cloggs the channels, thus increasing its water retentive abilities and also undermining its original function. Consequently, the moats may collect rainwater or seepage water and provide breeding sites for a number of mosquito species especially as they contain vegetations. More also, ponds being able to retain water and having been used to rear fishes which deposits organic matters within, pollute the water and make them favouarble breeding grounds for Anopheles species. This may have been the cause of higher occurrence of the mosquito species in the school dormitories in Ikpoba-Okha LGA.

The occurrence of established vectors such as $C x$. quinquefasciatus and An. gambiae s.lin these dormitories in the three Local Government Areas sampled is an indication that such habitats could contribute to vector disease risks - Filariasis and Malaria respectively inbthe dormitories and their associated areas.
Other species of mosquitoes encountered in this study including Cx. annulioris and Anopheles funestus albeit their exceptionally lower abundance $(0.5 \%$ and $0.1 \%$ respectively), are still classified as vectors of arboviral pathogens and Plasmodium species that cause a number of disease conditions (Okello et al. 2006; Service 2008; Muturi et al., 2008; and Oduola et al., 2012). However, in order to reduce the current high level of abundance of the bancroftian and malaria disease vectors - Cx. quinquefasciatus and An. gambiae s.l respectively, and other mosquito vector species encountered in this present study, management personnels of the various institutions surveyed, with the support and help oflocal or district education authorities in synchrony with Local Environmental Health Services, Department of Disease Control in the Ministry of Health and other relevant agencies, should ensure that 1 . there is a large scale distribution of insecticide treated bednets to students already inhabiting the dormitories, which could be done as an intervention once in a while and regularly 2. students come along with standard insecticide treated bednets before they are admitted into the dormitories for the academic session, 3. repair, replace or fix (as the case may warrant) proper nets on windows and doors, 4. initiate a regular environment friendly vector control programme directed at both the larval and adult stages of the mosquitoes, and 5. establish and sustain a clean environment policy.

\section{Conclusion}

The revibrating presence of $C x$. quinquefasciatus and to a lesser extent, $A n$. gambiae s.l. in the study locations strongly expose the inhabitants of the school dormitories and the locals around the vicinities of the respective schools to deadly diseases such as filariasis and malaria amongst many others. For this reason, there is an urgent need for properly planned periodical assessment, evaluation and implementation of vector control measures as all of these will significantly reduce the population of mosquito species and also the disease burden in and around the school dormitories and its surrounding environments. 


\section{References}

Adebote, D.A., Oniye, S.J. and Muhammed, Y.A. (2008). Studies on mosquitoes breeding in rock pools on inselbergs around Zaria, Northern Nigeria. Journal Vector Borne Diseases, 45: 21 - 28.

Adeogun, A.O., Popoola, K.O., Oduola, A.O., Olakiigbe, A.K. and Awolola, T.S. (2017). High level of DDT resistance and reduced susceptibility to deltamethrin in Anopheles gambiae, Anopheles coluzzi, and Anopheles arabiensis from Urban Communities in Oyo State, South-West Nigeria. Journal of Mosquito Research, 7(16): $125-133$.

Aigbodion, F.I. and Uyi, O.O. (2013). Temporal distribution of and habitat diversification by some mosquitoes (Diptera: Culicidae) species in Benin City, Nigeria. Journal of Entomology, 10(1): 13 - 23.

Aigbodion, F.I., Uyi, O.O., Akintelu, O.H. and Salau, L.A. (2011). Studies on some aspects of the ecology of Culex quinquefasciatus (Diptera: Culicidae) in relation to filarial infection in Benin City, Nigeria. European Journal of Experimental Biology, 1(4): 173 - 180.

Ajayi, M.B., Adedeji, S.O., Awolola, T.S., Idowu, E.T., Oduola, A.O. and Adeleke, M.A. (2011). Identification of malaria vectors in semi-urban area of Ogun state, South Western Nigeria. International Journal of Malaria and Tropical Diseases, 6: $215-219$.

Ajayi, M.B., Adeleke, M.A., Idowu, E.T. and Awolola, T.S. (2010). Surveillance of Mosquitoes in Ajumoni Estate Ogun State, Nigeria. Annals of Biological Research, 1(4): $16-19$.

Aju-Ameh, C.O., Awolola, T.S., Mwansat, G.S. and Mafuyai, H.B. (2016). Malaria Transmission indicies in two dominant Anopheles species in selected rural and urban communities in Benue state North Central, Nigeria. International Journal of Mosquito Research, 3(4): 31 - 35.

Aju-Ameh, O.C., Awolola, T.S., Mwansat, G.S. and Mafuyai, H.B. (2017). Molecular identification, species composition and distribution maps of malaria vector species in selected communities in Benue State, North Central Nigeria. IOSR
Journal of Biotechnology and Biochemistry, 3(2): $1-9$.

Awolola, T.S., Adeogun, A., Olakiigbe, A.K., Oyeniyi, T., Olukosi, Y.A., Okoh, H., Arowolo, T., Akila, J., Oduola, A. and Amajoh, C.N. (2018). Pyrethroids resistance intensity and resistance mechanisms in Anopheles gambiae from malaria vector surveillance sites in Nigeria. PLoS ONE, 13(12): e0205230.

Chinwe, E.Z., Ezihe, E.K. and Chidimma, C.M. (2018). Larval abundance, distribution and species composition of mosquitoes in Obio-Akpor LGA, Rivers State, Nigeria. International Journal of Entomological Research, 3(2): 85 - 90.

Ebomwonyi, A., Omoregie, A.O., Noutcha, M.A.E. and Okiwelu, S.N. (2015). Trents in malaria incidence rates $(2006-2013)$ in Edo State, Nigeria. International Journal of Tropical Diseases and Health, 7(2): $40-48$.

Gbaye, O.A., Afolabi, O.J., Simon-Oke, I.A. and Lasisi, A.O. (2017). Abundance and spatial distribution of mosquitoes across three ecological zones of Ondo State Nigeria. International Journal of Mosquito Research, 4(5): 23-27.

Gillett, J.D. and Smith, J.G. (1972). Common African mosquitoes and their medical importance. Willian Heineman medical Books LTD, 106p

Itina, V.I., Noutcha, M.A.E. and Okiwelu, S.N. (2014). Culicidae (Insecta: Diptera) of Akwa-Ibom state, Nigeria. European Journal of Experimental Biology, 4(3): $761-767$.

Mullen, G.R. and Durden, LA (Eds) (2009). Medical and Veterinary Entomology $2^{\text {nd }}$ Edition. Elsevier Academic Press. 637pp.

Mutebi, J.P., Crabtree, M.B., Kading, R.C., Powers, A.M., Lutwama, J.J. and Miller, B.R. (2012). Mosquitoes of Western Uganda. Journal of Medical Entomology, 49(6): 1289 - 1306.

Muturi, E.J., Muriu, S., Shililu, J., Mwangangi, J.M., Jacob, B.G., Mbogo, C., Githure, J. and Novak, R.J. (2008). Blood-feeding patterns of Culex quinquefasciatus and other culicines and implications for disease transmission in Mwea rice scheme, Kenya. Parasitology Research, 
102(6): $1329 \quad-\quad 1335 . \quad$ DOI: 10.1007/s00436-008-0914-7.

Mzilahowa, T., Luka-Banda, M., Uzalili, V., Mathanga, D.P., Campbell, J.R.C.H., Mukaka, M. and Gimnig, J.E. (2016). Risk factors for Anopheles mosquitoes in rural and urban areas of Blantyre District, southern Malawi. Malawi Medical Journal, 28(4): 154 - 158.

Nour, A.H., Sandanasamy, J.D. and Nour, A.H. (2012). Larvicidal activity of extracts from different parts of neem (Azadirachtaindica) against Aedesaegypti mosquitoes' larvae. Scientific Research and Essays, 7(31): 2810 - 2815.

Oduola, A.O., Otubanjo, O.A., Olojede, J.B., Oyewole, I.O. and Awolola, T.S. (2012). Malaria Transmission Risk Indices of Three Anopheles Species in selected Rural Communities in Oyo State SouthWestern Nigeria. International Journal of Tropical Medical, 7(1): $42-48$.

Ogbeibu, A.E. (2005). Biostatistics, a practical approach to research and data handling. Mindex publishing company limited, Ugbowo, pp 264.

Okello, P.E., Van Bortel, W., Byaruhanga, A.M., Correwyn, A. Roelants, P. Talisuna, A. D'Alessandro, U. and Coosemans, M. (2006). Variation in malaria transmission intensity in seven sites throughout Uganda. American Journal of Tropical Medicine and Hygiene 75: 219 - 225

Okiwelu, S.N. and Noutcha, M.A.E. (2012). Breeding sites of Culexquinquefasciatus (Say) during the rainy season in rural lowland rainforest, Rivers State, Nigeria. Public Health Research, 2(4): 64 - 68

Okogun, G.R.A., Anosike, J.C., Okere, A.N. and Nwoke, B.E.B. (2005). Ecology of Mosquitoes in Midwestern Nigeria. Journal of Vector Borne Diseases, 42: 1 -8 .

Okorie, P.N., Ademowo, G.O., Saka, Y., Davies, E., Okoronkwo, C., Bockarie, M.J., Molyneux, D.H. and Kelly-Hope, L.A. (2013). Lymphatic filariasis in Nigeria; micro-stratification overlap mapping
(MOM) as a prerequisite for costeffective resource utilization in control and surveillance. PLoS Neglected Tropical Disease, 7(9): e2416.

Okorie, P.N., Davies, E., Ogunmola, O.O., Ojurongbe, O., Saka, Y., Okoeguale, B. and Braide, E.I. (2015). Lymphatic filariasis baseline survey in two sentinel sites of Ogun state, Nigeria. Pan African Medical Journal, DOI: 10.11604/pamj.2015.20.397.5686.

Oringanje, C., Alaribe, A.A., Oduola, A.O., Oduwole, O.A., Adeogun, A.O., Meremikwu, M.M. and Awolola, T.S. (2011). Vector abundance and species composition of Anopheles mosquito in Calabar, Nigeria. Journal of Vector Borne Diseases, 48(3): 171 - 173.

Oyewole, I.O., Ibidapo, C.A., Okwa, O.O., Oduola, A.O., Adeoye, G.O., Okoh, H.I. and Awolola, T.S. (2010). Species composition and role of Anopheles mosquitoes in malaria transmission along Badagryaixis of Lagos lagoon, Lagos, Nigeria. International Journal of Insect Science 2: $51-57$.

Service, M.W. (2008). Medical Entomology for Students. $\quad 4^{\text {th }}$ Edition. Cambridge University Press, London.

Umeanaeto, P.U., Asogwa, A.N., Onyido, A.E., Irikannu, K.C. and Ifeanyichukwu, M.O. (2017). The parity rate of indoor-resting adult female Anopheles and Culex mosquitoes and their implication in disease transmission in Nnamdi Azikiwe University female hostels Awka, South Eastern Nigeria. International Journal of Environment, Agriculture and Biotechnology, 2(4): 1551 - 1556.

World Health Organisation (WHO) (1975). Manual of practical entomology on malaria, pt II. Geneva.

World Health Organisation (WHO) (2018). The World Malaria Report. [Online] W.H.O. Available from http://www.who.int /malaria/media/world-malaria-report2018/en/[Accessed 08/05/2019]. 